\title{
ZARZĄDZANIE MARKETINGOWE PARTIA POLITYCZNA W TEORIACH ROBERTA P. ORMRODA I STEPHANA C. HENNEBERGA
}

\author{
Agata Potarzycka-Szczerba* \\ MARKETING MANAGEMENT OF A POLITICAL PARTY \\ IN THE THEORIES OF ROBERT P. ORMROD \\ AND STEPHAN C. HENNEBERG
}

\begin{abstract}
Although political marketing management is still a very popular issue in modern political science, surprisingly, only few studies have tried to provide theoretical foundations for describing comprehensive marketing process in political parties. The aim of this paper is to present two complementary concepts developed by Robert P. Ormrod and Stephan C. Henneberg: Political Market Orientation and Strategic Political Postures. Both authors have prepared a theoretical framework for complex analysis of marketing operations in the parties. They consider political marketing management to be a permanent process which includes mainly building and maintaining relations with various stakeholders and creating strategies. The article presents these concepts from the perspective of previous studies and criticizes some assumptions in purpose to indicate possibilities and barriers of future empirical work.
\end{abstract}

\section{KEYWORDS}

political marketing, marketing management, political party, marketing strategy, political market

* Uniwersytet Wrocławski, Instytut Politologii. 
Partie polityczne stanowią ze swej istoty pomost pomiędzy obywatelami, którzy owe instytucje tworzą, wybierają lub kształtują ich działania, a władzą, do której członkowie ugrupowań aspirują, by mieć wpływ na tworzenie polityki, warunkującej życie obywateli. Ten system wzajemnych powiązań wymusza od organizacji politycznych stałą komunikację z otoczeniem, od którego zależny jest ich byt. I to nie tylko $\mathrm{z}$ wyborcami, na których to orientacja stanowi podstawę filozofii marketingowej. Istotny jest cały, znacznie szerszy kontekst funkcjonowania na rynku politycznym, obejmujący takie podmioty, jak: media, grupy interesu czy konkurentów, ale także uwarunkowania historyczne czy kulturowe. Tylko takie holistyczne ujęcie rywalizacji w pełni oddaje ducha marketingu politycznego traktowanego jako proces społeczny oparty na zasadach wymiany w celu zapewnienia satysfakcji wszystkim uczestnikom ${ }^{1}$. Wymiana ta dotyczy różnych wartości. Jak wskazuje Dariusz Skrzypiński, wyborcy, sympatycy i członkowie partii oprócz oczywistego dobra, jakim są głosy wyborcze i poparcie, oferują wybranemu ugrupowaniu także swoje uczestnictwo, lojalność, wiedzę oraz umiejętności i informacje ${ }^{2}$. W zamian partia polityczna przygotowuje dla nich określoną ofertę - program wyborczy, obietnice konkretnych rozwiązań, określone zmiany systemowe, kandydatów gwarantujących poczucie bezpieczeństwa itd.

W jaki sposób przebiega proces zarządzania marketingowego w partiach politycznych? To podstawowe pytanie, na które odpowiedź starają się przedstawić zaprezentowane w niniejszym artykule koncepcje. Choć zagadnienie wykorzystania marketingu przez organizacje polityczne jest poruszane w światowej i polskiej literaturze często, niewiele opracowań całościowo przygląda się marketingowym zachowaniom partii politycznych przez cały okres ich funkcjonowania, a nie tylko w czasie kampanii wyborczej. Należy zwrócić uwagę, że przecież to spójną i permanentną komunikację partii z otoczeniem określa się mianem „profesjonalnej”, a więc takiej, która opiera się na solidnym planie strategicznym, jego realizacji i stałej rewizji założeń na podstawie badań opinii publicznej. Szczególna uwaga autora została tu poświęcona zintegrowanej koncepcji politycznej strategii marketingowej, która stara się połączyć zagadnienia struktury organizacyjnej partii z procesem przetwarzania informacji i opracowywania spójnych założeń dla przyszłych działań.

${ }^{1}$ M. Mazur, Marketing polityczny, Warszawa 2002, s. 18.

2 D. Skrzypiński, Planowanie strategii komunikacyjnej partii politycznej. Analiza marketingowa, [w:] Marketing polityczny w poszukiwaniu strategii wyborczego sukcesu, red. M. Jeziński, Toruń 2004, s. 38 . 


\section{STRATEGIE MARKETINGOWE PARTII POLITYCZNYCH}

Klasyk marketingu Philip Kotler zauważył, że „głównym wyzwaniem dla współczesnych przedsiębiorstw jest zbudowanie i utrzymanie dobrze funkcjonującego biznesu w szybko zmieniającym się otoczeniu rynkowym"3. Zasada ta łatwo przekłada się także na pole marketingu politycznego. Dynamiczne środowisko wymusza ciągłe dostosowywanie polityki partii do zmieniających się warunków funkcjonowania na rynku politycznym. Jednocześnie muszą one dbać o realizację jednego z podstawowych celów, jakim jest przetrwanie. Stąd konieczność tworzenia systemu gromadzenia informacji, projektowania dalszych działań i zarządzania zasobami partii, a więc planowania strategicznego.

Pojęcie strategii znane już od czasów starożytnych, doczekało się wielu definicji i szerokiego zastosowania w różnych dziedzinach. W naukach politycznych strategia określana jest jako „racjonalna sugestia i hipoteza co do ewolucji stosunków politycznych w bliższej lub dalszej perspektywie czasowej, na podstawie której elity polityczne formułują konkretne już wytyczne co do ogólnego kierunku postępowania oraz konkretnych już rozstrzygnięć" ${ }^{4}$. Celowość, trwały charakter i bieżąca rewizja założeń to elementy łączące większość definicji tego pojęcia, zarówno politologicznych, jak i ekonomicznych.

Postawienie granicy między konceptami strategii politycznej i marketingowej jest w praktyce trudne, ponieważ obie te sfery przenikają się. Michał Jaśniok proponuje, by pierwszą z nich traktować jako pewną „planową realizację celów politycznych" na podstawie subiektywnych interpretacji bieżącej sytuacji, dokonywanej przez podmioty polityczne, zaś drugą ująć bardziej instrumentalnie, jako „system reguł i zasad działania, które w sposób planowy wyznaczają ramy dla rynkowych przedsięwzięć operacyjnych podmiotu”" Przedstawione poniżej koncepcje pokażą jednak, że procesu projektowania strategii marketingowych nie można oddzielić od sposobu organizacji partii czy decyzji podejmowanych przez elity w mniej lub bardziej obiektywny sposób.

Wśród rozważań dotyczących marketingowego funkcjonowania partii politycznych pojawiło się stosunkowo niewiele opracowań. Główną osią, wokół której koncentrowały się rozważania badaczy, jest przystawalność koncepcji marketingu komercyjnego do warunków obowiązujących na rynku

${ }^{3}$ P. Kotler, Marketing. Analiza, planowanie, wdrażanie i kontrola, Warszawa 1994, s. 58.

${ }^{4}$ Leksykon politologii, red. A. Antoszewski, R. Herbut, Wrocław 1996, s. 391.

5 M. Jaśniok, Strategie marketingowe na rynku politycznym, Kraków 2007, s. 25. 
politycznym. Najbardziej bezpośrednie przełożenie zaproponował w latach dziewięćdziesiątych ubiegłego wieku Aaron O’Cass. Według niego partia zorientowana marketingowo to ta, która koncentruje się przede wszystkim na swoich wyborcach i także ku nim kierowane są wysiłki związane z gromadzeniem informacji. Przyznaje przy tym, że działania partii są determinowane również przez jej członków oraz grupy lobbingowe ${ }^{6}$. Koncepcji brakuje jednak szerszego spojrzenia na otoczenie partii i uwzględnienia pozaekonomicznych czynników warunkujących jej zachowanie.

Krok dalej poszła Jennifer Lees-Marshment. Na podstawie analizy działań brytyjskiej Partii Pracy skonstruowała wieloelementowy model procesu marketingowego, którego głównym podmiotem są partie. Jej koncepcja wszechstronnego marketingu politycznego obejmuje wszystkie zachowania organizacji politycznych, od zbierania informacji przez projektowanie produktu (traktowanego całościowo jako wszystkie aspekty działalności partii) po wdrażanie strategii i ocenę jej efektów. Nawiązując do modelu Bruce’a Newmana, wyróżniła trzy typy orientacji partii: na produkt, na sprzedaż oraz partię zorientowaną marketingowo. Każdemu odpowiada konkretny model procesu marketingowego. Zdaniem autorki najbardziej pożądany i efektywny sposób komunikacji zapewnia orientacja marketingowa, charakteryzująca się skrupulatnym projektowaniem i dostosowywaniem produktu na podstawie szerokiego wywiadu marketingowego oraz spójną komunikacją uzupełnioną wykorzystaniem technik sprzedażowych. Ostateczny sprawdzian stanowią wybory, po których organizacja dostarcza swój produkt wyborcom. Wtedy też cały proces rozpoczyna się na nowo, zamykając „wyborczy krąg”7.

Model Lees-Marshment doskonale sprawdza się podczas analizy funkcjonowania Partii Pracy, która na przestrzeni lat 1983-1997 przeszła ewolucję od orientacji produktowej po marketingową, sukces odnosząc dopiero wówczas, gdy zrealizowała wszystkie założenia wszechstronnego marketingu politycznego. Wątpliwości budzi jednak uniwersalność koncepcji, m.in. fakt, czy w warunkach odmiennych od brytyjskich, które są przecież specyficzne choćby ze względu

${ }^{6}$ A. O'Cass, Political Marketing and the Marketing Concept, „European Journal of Marketing” 1996, vol. 30 (10/11), s. 1003-1025, [za:] R.P. Ormrod, Political Market Orientation and Its Commercial Cousin: Close Family or Distant Relatives?, „Journal of Political Marketing” 2007, vol. 6 (2/3), s. 80-81.

7 W. Cwalina, A. Falkowski, Marketing polityczny. Perspektywa psychologiczna, Gdańsk 2005, s. 47-54; J. Lees-Marshment, Political Marketing and British Political Parties. The Party's just Begun, Manchester 2001. 
na charakterystyczny system partyjny, powyższe założenia zostają spełnione. Ponadto warto zastanowić się, czy rzeczywiście założenia marketingowe mogą być wdrażane do polityki partii wyłącznie według jednego wzoru.

\section{KONCEPCJA ORIENTACJI NA RYNEK POLITYCZNY (POLITICAL MARKET ORIENTATION)}

Duński naukowiec Robert P. Ormrod, po analizie opracowań dotyczących planowania strategii marketingowych zarówno przez przedsiębiorstwa komercyjne, jak i przez partie polityczne, zaproponował własną koncepcję - orientacji na rynek polityczny (Political Market Orientation). Łączy ona proces gromadzenia i przetwarzania informacji z uwzględnianiem potrzeb grup, które dana strategia ma realizować. Autor zakłada, że partia jest zorientowana na rynek wówczas, gdy wszyscy jej członkowie są wrażliwi na potrzeby, pragnienia i postawy wewnętrznych i zewnętrznych grup otoczenia ${ }^{8}$ oraz łączą je dla opracowania programów, z którymi mają zostać osiągnięte cele organizacji ${ }^{9}$. Planowanie strategiczne odbywa się zatem w ramach presji wywieranej przez grupy otoczenia, takie jak: wyborcy, konkurencja, media, ale także partyjni członkowie. Szczególne znaczenie przypisane zostało także informacji jako kluczowemu elementowi przewidywania zachowań powyższych grup i włączania członków partii do procesu formułowania polityki ${ }^{10}$. Opierając się na powyższych założeniach, Ormrod wyróżnia dwa wymiary orientacji na rynek polityczny. Pierwszy - behawioralny - dotyczy procesu formułowania strategii poprzez gromadzenie i przetwarzanie

8 Pojęcie grupy otoczenia wydaje się nieostre, zwłaszcza w odniesieniu do później opisanego czwartego elementu - Orientacji Społecznej, która swym zasięgiem oprócz mediów czy związków zawodowych obejmuje również np. kulturę polityczną. W oryginalnym opracowaniu autorzy używają sformułowania stakeholders, które w przytoczonym kontekście trudno przełożyć wprost na język polski. Krzysztof Obłój i Maciej Trybuchowski zaliczają do nich „organizacje i grupy w otoczeniu firmy, które są w jakiś sposób uzależnione od jej funkcjonowania i (lub) które wpływają (mogą wpływać) na nią" (Zarządzanie. Teoria i praktyka, red. A.K. Koźmiński, W. Piotrowski, Warszawa 1996, s. 189). W kontekście przytaczanej koncepcji sformułowanie grupy otoczenia wydaje się najlepiej oddawać sens tego pojęcia.

9 R.P. Ormrod, A Conceptual Model of Political Market Orientation, „, Journal of Nonprofit and Public Sector Marketing” 2005, vol. 14 (1/2), s. 51.

${ }^{10}$ Idem, Political Market Orientation and Its Commercial Cousin: Close Family or Distant Relatives?, „Journal of Political Marketing” 2007, vol. 6 (2/3), s. 69. 
informacji. Drugi bierze pod uwage postawy, czyli nastawienie partii na realizację potrzeb konkretnych grup otoczenia.

Wymiar behawioralny koncepcji odnosi się do czterech konstruktów zachowań. Razem tworzą one łańcuch następujących po sobie etapów tworzenia strategii.

1. Wytwarzanie informacji (Information Generation) - dotyczy gromadzenia formalnych i nieformalnych danych na temat wszystkich wewnętrznych i zewnętrznych grup odniesienia.

2. Rozprzestrzenianie informacji (Information Dissemination) - odnosi się do sfery komunikacji i przyswajania zdobytej wiedzy wewnątrz organizacji, z wykorzystaniem kanałów formalnych i nieformalnych.

3. Partycypacja członków (Member Participation) - obejmuje proces włączania wszystkich członków partii w projektowanie jej spójnej strategii; istotne znaczenie ma tutaj ogólna akceptacja przyjętych rozwiązań.

4. Spójna komunikacja zewnętrzna (Consistent External Communication) wiąże się z etapem konsekwentnej implementacji uzgodnionej strategii, czyli komunikowania jej do zewnętrznych grup odniesienia ${ }^{11}$.

Drugi wymiar, wyodrębniony ze względu na postawy przyjmowane przez partie podczas formułowania strategii marketingowych względem grup odniesienia, również obejmuje cztery konstrukty. Występują one niezależnie od siebie. O ile jednak behawioralne ujęcie orientacji na rynek polityczny jest w dużej mierze zbieżne z podejściem marketingu komercyjnego, określenie postaw partii wymaga uwzględnienia specyficznego charakteru środowiska politycznego. Widać to szczególnie w dwóch ostatnich konstruktach - orientacji wewnętrznej i społecznej.

1. Orientacja na wyborcę (Voter Orientation) - wszyscy członkowie partii są nastawieni na realizację potrzeb i pragnień wyborców. Dlatego też wykorzystują szeroki wachlarz tradycyjnych narzędzi badań marketingowych w celu poznania jawnych i ukrytych opinii elektoratu.

2. Orientacja na konkurentów (Competitor Orientation) - uwzględnia tę właściwość rynku politycznego, iż partie, konkurując ze sobą, biorą także pod uwagę ewentualne możliwości koalicyjne po wyborach, konieczne, by osiągać długoterminowe cele organizacji.

3. Orientacja wewnętrzna (Internal Orientation) - partia szczególną uwagę kieruje na wszystkich członków, także tych z najniższych szczebli partyj-

11 Idem, A Conceptual Model..., op.cit., s. 53-56. 
nej hierarchii i w formułowaniu strategii akceptuje wartość wszystkich opinii ${ }^{12}$.

4. Orientacja społeczna (Societal Orientation) - we wcześniejszych opracowaniach była nazywana orientacją zewnętrzną (External Orientation). Odnosi się do szeroko pojętego środowiska społecznego i kulturowego, w którym toczy się rywalizacja polityczna. Uwzględnia zatem pozostałe grupy otoczenia, które mogą mieć wpływ na politykę ugrupowania na poziomie mikro (np. obywatele), mezo (np. grupy interesu, lobby, związki zawodowe) oraz makro (media masowe) ${ }^{13}$.

Wykorzystując strukturę relacji, jakie przedstawia konceptualny model orientacji na rynek polityczny, możliwe jest określenie kierunku formułowania strategii przez partię, najlepszego dla realizacji jej długofalowych celów ${ }^{14}$. Pozwala na to uwzględnienie $\mathrm{w}$ analizie wszystkich relewantnych grup otoczenia, które ugrupowanie powinno brać pod uwagę w procesie planowania swoich działań.

\section{KONCEPCJA STRATEGICZNEJ POZYCJI POLITYCZNEJ (STRATEGIC POLITICAL POSTURES)}

Niedostatki w tłumaczeniu znaczenia koncentracji partii na wyborcach, do której odwołują się m.in. J. Lees-Marshment i A. O’Cass, dostrzegł również Stephan C. Henneberg. W swojej pracy skoncentrował się na przedstawieniu zagadnienia orientacji strategicznej, którą partie przyjmują w celu kreowania własnej pozycji w oczach elektoratu, konkurentów i własnych członków. Kreowanie strategicznego położenia politycznego zaczyna się od umiejscowienia względem dwóch wymiarów: przewodzenia opinii publicznej oraz jej kreowania. W ten sposób partia określa swoją konkurencyjną pozycję ${ }^{15}$.

Przewodzenie opinii publicznej (leading) dotyczy kierowania uwagi otoczenia politycznego na produkt partii lub kandydata (np. program) i przekonywania, że jest to najlepsza oferta istniejąca na rynku. Wysiłki są zatem skierowane

12 Ibidem, s. 57-59.

13 R.P. Ormrod, S.C. Henneberg, An Investigation into the Relationship between Political Activity Level and Political Market Orientation, „European Journal of Marketing” 2008, s. 10.

14 R.P. Ormrod, A Conceptual Model..., op.cit., s. 60.

15 S.C. Henneberg, Strategic postures of political marketing, „Journal of Public Affairs” 2006, vol. 6, s. 17. 
przede wszystkim na komunikowanie o zaletach istniejącego już produktu, co do którego wartości partia jest przekonana. Drugim wymiarem kształtowania postaw elektoratu jest podążanie za zapotrzebowaniem rynku (following). Partia kreuje swoją ofertę w oparciu o dokładne rozpoznanie potrzeb, pragnień i oczekiwań największej możliwej liczby wyborców. Oba wymiary nie wykluczają się, wręcz przeciwnie - współwystępują jako dwie strony tej samej monety. Warto tu zaznaczyć, że przewodzenie opinii w marketingowym sensie musi zawierać element przyglądania się nastrojom otoczenia w celu uzupełniania oferty ${ }^{16}$. Jak zostanie to zaprezentowane poniżej, model zakłada m.in. istnienie ugrupowań, które charakteryzują się wysokim poziomem zarówno przewodzenia opinii, jak i dostosowywania swojej oferty zgodnie z aktualnym zapotrzebowaniem rynku.

Biorąc pod uwagę dwie opisane zmienne, Henneberg naszkicował cztery typy idealne orientacji strategicznych partii politycznych. Przekonani Ideolodzy (Convinced Ideologist) charakteryzują sie wysokim poziomem przewodzenia opinii publicznej, zaś niskim podążania za nią. To partia, która jest przekonana co do słuszności i wartości własnej oferty politycznej i promuje ją jako gotowy produkt wśród wyborców. Stara się przede wszystkim kształtować opinie grup otoczenia, zamiast słuchać ich głosów. Przeciwieństwem są Taktyczni Populiści (Tactical Populist). Charakteryzuje ich niski poziom kształtowania opinii publicznej, lecz wysoki kreowania własnej oferty zgodnie z jej oczekiwaniami. Ta silna koncentracja na wyborcach sprawia, że program, działania czy kandydaci partii są wyraźnie powiązani z konkretnymi, wyrażanymi jawnie lub ukrytymi, potrzebami i pragnieniami elektoratu. Wiąże się to z częstymi, nagłymi zmianami oferty. Mianem Budowniczych Relacji (Relationship Builder) Henneberg określa te ugrupowania, które punktują wysoko zarówno na osi przewodzenia, jak i podążania za opinią publiczną. Koncentrują się na długoterminowym budowaniu i podtrzymywaniu pozytywnych relacji z otoczeniem. Posiadają umiejętność szybkiego reagowania na zmiany, przy jednoczesnym formułowaniu oferty na podstawie własnej spójności ideowej i podzielanych przez członków partii przekonań ${ }^{17}$. Ostatni z modeli - Polityczna Waga Lekka (Political Lightweight) - został przez autora odrzucony jako niemożliwy do zaistnienia w praktyce. Zakłada bowiem niski poziom obu zmiennych, co sprawia, że partia zostaje pozbawiona podstaw funkcjonowania - nie ma żadnej ideologii, na której

\footnotetext{
16 Ibidem, s. 17.

17 Ibidem, s. 18.
} 
opiera swój program, jak również nie kieruje się w jego opracowywaniu żadnymi wskaźnikami zewnętrznymi.

\section{ZINTEGROWANA KONCEPCJA POLITYCZNEJ STRATEGII MARKETINGOWEJ (INTEGRATED CONCEPT OF POLITICAL MARKETING STRATEGY)}

Analizy Henneberga i Ormroda doprowadziły ich do wniosku, iż każdej strategicznej pozycji powinien odpowiadać określony model orientacji na rynek polityczny. W zależności od wzoru interakcji partii z otoczeniem formułuje ona swoją ofertę w konkretny sposób. I tak partia określana jako Przekonani Ideolodzy, koncentrując się na sprzedawaniu własnej oferty wyborcom, do najważniejszych grup otoczenia zalicza własnych członków oraz organizacje, które w różny sposób są z nią powiązane: historycznie (np. związki zawodowe), poprzez podobne cele długo- lub krótkoterminowe (np. ruchy ekologiczne dla partii zielonych) lub tzw. „podwójne członkostwo” polityków. To ich przekonania kształtują program i działania ugrupowania. W sam proces projektowania strategii, wyznaczania celów ugrupowania i określania technik ich realizacji angażuje się relatywnie duża liczba członków partii. Jednocześnie najmniejsza uwaga poświęcana jest działaniom konkurencji ${ }^{18}$.

Wręcz odwrotna sytuacja ma miejsce w procesie formułowania strategii przez Taktycznych Populistów. Ponieważ cele, które sobie wyznaczają, są zazwyczaj krótkoterminowe, mianem kluczowych należy określić działania zmierzające do inicjowania, podtrzymywania, ale i kończenia relacji z rozmaitymi grupami otoczenia $^{19}$. Do najważniejszych zaliczyć trzeba wyborców (przede wszystkim niezdecydowanych), ale także media, których zainteresowanie jest istotnym warunkiem budowania popularności ugrupowania. Stąd też kluczowym etapem planowania jest gromadzenie informacji o ukrytych i utajonych potrzebach, pragnieniach i oczekiwaniach wyborców. Ugrupowanie aktywnie reaguje również na zachowanie konkurencji. Projektowaniem celów i działań zajmuje się wąskie grono polityków i profesjonalistów, a szeregowi członkowie przyjmują postawę

18 R.P. Ormrod, S.C. Henneberg, Strategic Political Postures and Political Market Orientation: Toward an Integrated Concept of Political Marketing Strategy, , Journal of Political Marketing” 2010, vol. 9, s. 303-304.

19 Ibidem, s. 304. 
pasywną. Ułatwia to spójne wdrażanie przygotowanej strategii ${ }^{20} . \mathrm{Z}$ drugiej strony w takiej konfiguracji funkcji na barkach wąskiej elity spoczywa również odpowiedzialność za wynik wyborów jako ostatecznego sprawdzianu słuszności podejmowanych decyzji.

Budowniczych Relacji charakteryzują silne korelacje pomiędzy wszystkimi elementami orientacji na rynek polityczny. Zatem koncentrują się na stałym rozpoznawaniu i analizie opinii oraz zachowań wszystkich grup otoczenia wewnętrznego i zewnętrznego. W zależności od dostępnych zasobów ustalają jednak priorytety kierunków, w których w danej chwili budują i podtrzymują relacje. Członkowie partii aktywnie uczestniczą w procesie gromadzenia danych, mogą także swobodnie wyrażać własne opinie i są wtajemniczani w rozwiązania proponowane przez partyjne elity ${ }^{21}$. Czynnikiem decydującym jest wciąż ideologia partii. Liczy się kompromis pomiędzy nią a oczekiwaniami grup otoczenia.

Koncepcje Ormroda i Henneberga to z pewnością ciekawe, a dla marketingu politycznego także nowe podejście do procesu formułowania strategii. Zawierają wiele elementów zaadaptowanych $\mathrm{z}$ badań nad funkcjonowaniem organizacji komercyjnych i dostarczają narzędzi umożliwiających przełożenie założeń teoretycznych na grunt praktyki. W swoich badaniach empirycznych stosowali metodę ilościową ${ }^{22}$, obejmującą badania ankietowe na próbie złożonej z członków badanych partii. Niemniej zarówno sposób przedstawienia przebiegu procesu strategicznego w instytucjach politycznych, jak i zastosowana metoda, mogą budzić pewne zastrzeżenia.

Jedno z nich dotyczy ram interpretacyjnych omawianego zjawiska. Strategia marketingowa została ograniczona przez Ormroda i Henneberga do trzech wymiarów: informacji (jej zdobywania, rozpowszechniania i przetwarzania), kształtowania i odbierania relacji z grupami otoczenia zewnętrznego i wewnętrznego oraz generalnego kierunku, jaki wybierają decydenci podczas przygotowywania oferty (przewodzenie czy podążanie za opinią publiczną). Sam proces skoncentrowany jest w zasadzie wyłącznie na informacji i nie wyjaśnia, w jaki sposób członkowie partii mogą partycypować w podejmowaniu strategicznych decyzji. Autorzy wymieniają spójną komunikację zewnętrzną jako etap finalny prac nad strategią, ale wydaje się on niemożliwy do oceny tylko z perspektywy

20 Ibidem, s. 305.

21 Ibidem, s. 306-307.

${ }^{22}$ Więcej na temat metody badawczej w Zintegrowanej Koncepcji Politycznej Strategii Marketingowej zob. R.P. Ormrod, S.C. Henneberg, Political Market Orientation and Strategic Political Postures in Danish Political Parties, „European Journal of Marketing” 2011, vol. 45, s. 852-881. 
wewnętrznej. To, jaki wizerunek ma partia, zależy od jego percepcji w otoczeniu. Działania partii zmierzające do wykreowania takiego, a nie innego obrazu, są tylko środkiem do osiągnięcia pożądanego image. W procesie zaproponowanym przez autorów brakuje również bardzo istotnego elementu, jakim jest ewaluacja dotychczasowych efektów, etap, który gwarantuje ciągłość funkcjonowania instytucji i zasadność podejmowanych przez nią decyzji.

Otwarta pozostaje kwestia, czy obszar zróżnicowanych wpływów, w którym silne znaczenie mają czynniki nie zawsze związane z rynkową racjonalnością, jest kwantyfikowalny i pozwala się zbadać w ściśle ilościowy sposób. Z jednej strony wprowadza to pewien porządek metodologiczny, ogranicza subiektywne oceny i pozwala na klarowne przedstawienie wyników badań. $Z$ drugiej jednak grozi zbyt dużym ograniczeniem zakresu obserwowanych zjawisk, pominięciem istotnych ram (np. kulturowych) oraz ważnych skutków czy przyczyn decyzji. Środowisko polityczne znacznie bardziej niż rynkowe jest narażone na wpływ takich czynników jak chociażby psychologiczne, związane z predyspozycjami liderów, czy historyczne, warunkujące układ sił na rynku politycznym. To cechy, które metoda zaproponowana przez autorów w zasadzie całkowicie pomija, a mogą oddziaływać choćby na takie jej elementy jak postrzeganie konkurencji lub wewnętrzny sposób organizacji partii.

\section{PODSUMOWANIE}

Inżynieryjne podejścia do marketingu politycznego, sprowadzające to pojęcie do zespołu metod i technik służących kształtowaniu zachowań wyborców, choć wciąż popularne budzą jednak zastrzeżenia części badaczy. Poruszają istotny aspekt procesów marketingowych związany z ich fundamentalną funkcją maksymalizacji wyniku wyborczego, ale brakuje w nich czynnika, który pozwalałby odróżnić wybiórcze sięganie po określone narzędzia od holistycznego programowania funkcjonowania organizacji. Tę granicę starają się uchwycić R.P. Ormrod i S.C. Henneberg, odwołując się do wywiedzionej z marketingu komercyjnego koncepcji orientacji organizacji na rynek, która akcentuje konieczność permanentnego budowania relacji z różnorodnymi grupami otoczenia wewnętrznego i zewnętrznego. Orientacja partii na rynek polityczny polega na stałym balansowaniu między potrzebami, pragnieniami i oczekiwaniami pojawiającymi się $\mathrm{w}$ środowisku wewnętrznym i zewnętrznym. Marketing pełni w tym względzie $\mathrm{z}$ jednej strony funkcje stabilizujące, tzn. zapewnia procedury umożliwiające 
szybkie rozpoznawanie sytuacji i reagowanie na zmiany, a z drugiej adaptacyjne, dzięki czemu partia ewoluuje w sposób zgodny z jej tożsamością, ale i oczekiwaniami elektoratu, własnych członków i pozostałych stakeholders.

Wciąż niewiadomą pozostaje fakt, do jakiego stopnia modele zarządzania marketingowego charakterystyczne dla organizacji komercyjnych mogą być przekładane na skomplikowany grunt polityki. Rozwiązania tych problemów nie ułatwia problem barier dostępu do empirycznych danych związanych z planowaniem strategicznym parti oraz relatywnie niewielka liczba badań prowadzonych na tym polu. Zintegrowana koncepcja politycznej strategii marketingowej to podejście, które może dostarczyć wiele ciekawych wniosków w tym zakresie, gdy zostanie zderzone ze sferą praktyki politycznej. Niemniej należy zdawać sobie sprawę z ograniczeń teorii, by nie pominąć istotnych niuansów warunkujących funkcjonowanie rynku politycznego i jego uczestników. 